\title{
ANALISIS UNSUR INTRINSIK DAN EKSTRINSIK PADA FILM FESTIVAL ANTI KORUPSI TAHUN 2015 YANG BERJUDUL "TINUK"
}

\author{
Fitria Apriyana ${ }^{1}$ \\ Universitas Muhammadiyah Lampung $^{1}$ \\ fitria.apriyana28@gmail.com ${ }^{2}$ \\ Salamah $^{2}$ \\ Universitas Muhammadiyah Lampung ${ }^{2}$ \\ salamahchalma@gmail.com ${ }^{2}$ \\ Idawati $^{3}$ \\ Universitas Muhammadiyah Lampung ${ }^{3}$ \\ idawati473@gmail.com ${ }^{3}$
}

\begin{abstract}
ABSTRAK
Penelitian ini dilakukan untuk mengetahui serta mendeskripsikan unsur intrinsik dan ekstrinsik dalam film festival anti korupsi tahun 2015 yang berjudul Tinuk. Penelitian dilakukan untuk mengetahui tentang makna film lebih mendalam. Metode penelitian pada film Tinuk menggunakan metode penelitian kualitatif, sebab dalam tindakannya peneliti mendeskripsikan unsur instrinsik dan unsur ekstrinsik pada sebuah film, yakni : tema, alur, sudut pandang, tokoh, amanat, latar, nilai moral, keadaan politik saat film dibuat dan latar belakang pembuatan film. Analisis data yang dilakukan pada film dengan cara menonton serta memahami film kemudian menganalisis unsur intrinsik dan ekstrinsiknya setelah itu mendeskripsikan hasil temuan yang diakhiri dengan menyimpulkan hasil penelitian. Hasil penelitian yang dilakukan pada film festival anti korupsi tahun 2015 yang berjudul Tinuk dapat disimpulkan bahwa film Tinuk yang berdurasi 15 menit ini terkandung makna yang tersirat untuk keadaan kehidupan masyarakat saat ini. Film ber-genre drama ini adalah bentuk sindiran terhadap tindakan korupsi di Indonesia. Film Tinuk merupakan film yang mengandung nilai moral kejujuran sehingga film ini dijadikan sebagai bahan kampanye oleh Komisi Pemberantasan Korupsi (KPK).
\end{abstract}

Kata kunci: unsur intrinsik, unsur ekstrinsik, film.

\section{A. PENDAHULUAN}

Film merupakan salah satu produk sastra Indonesia yang memperlihatkan keragaman suku bangsa serta adat istiadat tertentu yang ada di Indonesia yang disajikan dengan cara yang unik dan lebih menarik. Film dapat dikatakan sebagai strukturalisasi pengalaman mulai dari pengalaman pribadi, hasil riset, kolektif maupun pengalaman orang lain. Pengalaman menjadi bahan dasar pengarang dalam pembuatan sebuah karya yang telah ditambah serta dikombinasikan dengan ide pikiran yang imajinatif pengarang. Bertumpu kepada konsep karya sastra Rokhmansyah (2014), mengatakan sastra merupakan suatu hasil karya sastra dari seorang pengarang, dimana proses penciptaannya melalui proses pemikiran 


\section{Lingua Rima: Jurnal Pendidikan Bahasa dan Sastra Indonesia \\ Vol. 11 No. 1 Januari 2022 \\ http://jurnal.umt.ac.id/index.php/lgrm}

serta perenungan pengarang akan hakikat kehidupan. Sehingga dapat dikatakan, karya sastra suatu gambaran masalah dalam hidup manusia. Film adalah karya nyata yang telah dicampur aspek imajinatif dalam wadah tulisan yang dijadikan dokumentasi sosial sehingga menjadi penting bagi kalangan masyarakat serta pengemarnya.

Karya sastra diciptakan pengarang bukanlah tanpa tujuan dan bukan pula memamerkan hasil karyanya, melainkan pengarang ingin menyampaikan suatu hal yang bermanfaat bagi kehidupanmanusia. Pengalaman serta permasalahan kehidupan dihidangkan oleh seorang pengarang dalam bentuk karya sastra. Karya sastra harus mengandung cerita menarik yang merupakan bangunan terstruktur serta tetap memiliki nilaiseni. Hal inilah yang pertama kali akan memotivasi penonton untuk menghargai film yang dilihat atau menganalisis suatu karya. Mempelajari karya sastra tidak akan pernah usai, hal ini efek dari kehidupan dunia yang berkaitan dengan sastra.

Film dapat dijadikan sebagai alat komunikasi guna menyampaikan pesan kepada sekelompok orang dengan cara audio visual. Effendy (2014) mengemukakan komunikasi masa pada film memiliki pesan sesuai misi dari film tersebut. Film ialah suatu bentuk karya sastra yang menceritakan kisah hidup dalam penyampaiannya dengan lakuan dan dialog. Karya film adalah miniatur kehidupan yang bersumber dari kisah nyata sosial yang telah dicampur ide imajinasi penulis naskah. Oleh karena itu, karya yang dikemas dalam bentuk film bisa dikatakan sastra. Sehingga, film dapat dijadikan sebagai objek penelitian. selanjutnya film dirujuk sebuah karya sastra guna dilakukannya penelitian terkait unsur intrinsik dan ekstrinsik yang terkandung dalam film.

Penelitian unsur intrinsik dan ekstrinsik pada film sebelumnya pernah dilakukan yang serupa dalam sebuah artikel pada Film Indonesia yang berjudul "Do'a untuk Ayah" penelitian ini dilakukan pada tinjauan unsur intrinsik dan ekstrinsiknya. Tinjauan pada film dilakukan untuk mengetahui budaya serta latar belakang sosial para pemeran film. penelitian ini menjelaskan sebuah karya film ialah bagian dari kisah nyata kehidupan yang dijadikan sebuah karya serta keadaan politik yang sedang terjadi pada saat itu yang telah dicampur imajinasi sutradara. Atas dasar itu karya film adalah karya sastra.

Penelitian kajian unsur intrinsik dan unsur ekstrinsik banyak dilakukan dalam novel seperti penelitian yang dilakukan oleh Elizabeth Wahyuni dengan judulnya "Analisis Unsur Intrinsik dan Ekstrinsik Novel Surat Kecil Untuk Tuhan Karya Agnes Davonar Sebagai Sumbangan Materi Bagi Pengajaran Sastra". Novel dari kisah nyata yang menceritakan 


\section{Lingua Rima: Jurnal Pendidikan Bahasa dan Sastra Indonesia \\ Vol. 11 No. 1 Januari 2022 \\ http://jurnal.umt.ac.id/index.php/lgrm}

perjalanan hidup. Mulai dari perjuangan hidup, kesabaran serta pengorbanan seseorang untuk orang-orang yang mereka cintai. Penelitian novel yang dilakukan mulai dari penokohan yang menggambarkan sosok tokoh dan watak tokohnya, latar yang dibagi menjadi tiga, yaitu: waktu, tempat, sosial serta tema pada novel yang merupakan kajian unsur intrinsik dan ekstrinsik.

Intrinsik merupakan unsur utama dalam membangun utuhnya suatu film. Unsur intrinsik mencakup beberapa aspek, yaitu: tema, amanat, tokoh, konflik, bahasa, alur serta latar. Sedangkan ekstrinsik adalah unsure bagian luar sebagai pendukung pada film. Unsur ekstrinsik mencakup beberapa aspek yang tampak dalam film seperti, perilaku, sikap hidup, pola pikir dan etika serta kondisi sosial budaya pada perkembangan zaman saat itu. Karya sastra, seni maupun film unsur intrinsik dan unsur ekstrinsik memiliki peran yang sangat penting. Kedua unsur tersebut menjadikan suatu karya menjadi lebih bermakna, indah dan menarik. Suatu karya akan lebih berkualitas bila kedua unsur ini diperhatikan dalam ciptaan suatu karya guna mengetahui lebih mendalam tentang makna yang terkandung.

Bagian pembahasan dalam penelitian ini dalam tindakannya peneliti mengidentifikasi unsur intrinsik dan unsur ekstrinsik pada sebuah film yakni : tema, alur, tokoh, latar, sudut pandang, latar belakang film, nilai moral, kodisi politik negara dan sebagainya. Data yang diperoleh akan dianalisis dan diuraikan secara objektif kemudian dideskripsikan. Unsur intrinsik merupakan unsur pokok atau inti sebuah karya. Nurgiyantoro (2009) berpendapat bahwa unsur-unsur intrinsik yang secara langsung ikut serta dalam membangun cerita meliputi:

a) Peristiwa sebagai alur cerita atau kejadian-kejadian pada isi cerita dalam film yang diperankan para tokoh. Peristiwa ini dapat dikatakan sebagai konflik yang terjadi pada cerita film. peristiwa merupakan masalah, pertikaian serta pertentangan yang dialami para tokoh.

b) Penokohan sebagai unsur terpenting dalam membangun sebuah cerita. dari penokohan yang dibuat pengarang akan tampil para tokoh pada cerita untuk mengetahui karakter para pemeran.

c) Tema merupakan dasar pokok ide dari cerita film. Tema dapat diibaratkan suatu pohon yang memiliki akar sebagai penopang agar pohon menjadi hidup. Tema cerita bisa terkait persoalan moral, etika, agama, sosial budaya dan persoalan lainnya. 


\section{Lingua Rima: Jurnal Pendidikan Bahasa dan Sastra Indonesia \\ Vol. 11 No. 1 Januari 2022 \\ http://jurnal.umt.ac.id/index.php/lgrm}

d) Alur merupakan peristiwa yang dijalan dengan baik sesuai jalan cerita dari awal, tengah hingga mencapai klimaks dan akhir cerita. Para pemeran digambarkan dalam cerita dengan satu kesatuan waktu yang saling berkaitan.

e) Latar adalah tempat atau lokasi kejadian peristiwa itu berlangsung pada setiap alur cerita. Latar pun mencakup atribut dalam pementasan film seperti, peralatan, waktu, budaya, kostum dan kehidupan tokoh pada cerita.

f) Sudut pandang sebagai pandangan penulis dalam penyampaian cerita, sehingga cerita tersebut lebih bermakna dan hidup serta tersampaikan dengan baik kepada penikmat sastra. Sehingga sudut pandang dapat dikatakan sebagai cara pembuat karya sastra memandang atau menempatkan dirinya dalam sebuah cerita.

g) Amanat merupakan pesan yang diberikan pengarang kepada penulis melalui karya yang diciptakannya.

Selain unsur intrinsik terdapat pula unsur ekterinsik pada sebuah karya sastra yang menjadi unsur pendukung yang berada di luar karya sastra namun mempengaruhi kelahiran suatu karya sastra. Unsur ekstrinsik merupakan bagaian dalam membangun karya sastra lebih bernilai yang kaitannya pada sosial masyarakat. Nurgiyantoro (2009) berpendapat bahwa unsur ekstrinsik merupakan unsur-unsur yang keberadaannya di luar karya fiksi namun sangat berpengaruh terhadap lahirnya sebuah karya, tetapi tidak menjadikan bagian di dalam karya fiksi itu sendiri.

Unsur ekstrinsik adalah suatu keadaan tentang sikap pengarang serta pandangan hidup yang menjadi latar belakang terciptanya sebuah karya fiksi tersebut. Sedangkan unsur biografi pengarang adalah sebagai penentu ciri karya yang dihasilkan. Unsur ekstrinsik berkontribusi dalam memberikan gambaran luar, yang menghasilkan suatu produk karya yang menggiurkan dari olahan perasaan seorang pengarang. Sedangkan Nurgiyantoro (2018) mengatakan bahwa unsur ekstrinsik ialah aspek yang keberadaannya di luar karya sastra, namun mempengaruhi konstruksi pada sebuah karya sastra.Unsur ekstrinsik merupakan bagian segala macam unsur yang berada di luar naskah atau teks film, namun ikut berperan penting dalam keberadaan naskah film tersebut.

Karya sastra merupakan suatu imajinasi seseorang yang dikembangkan menjadi suatu hal yang indah serta menyenangkan yang disajikan penulis sebagai hiburan kepada penikmatnya. Menurut Amir (2013) sastra memiliki keindahan serta berfungsi sebagai hiburan, pendidikan, moral dan religius. Karya sastra dapat memberikan rasa senang kepada penikmatnya, dengan 


\section{Lingua Rima: Jurnal Pendidikan Bahasa dan Sastra Indonesia \\ Vol. 11 No. 1 Januari 2022 \\ http://jurnal.umt.ac.id/index.php/lgrm}

tidak menyampingkan aspek pendidikan melalui nilai yang terkandung di dalamnya. Sastra mengungkapkan perasaan, gagasan, pemikiran serta pengalaman seorang penulis yang dibangkitkan ke bentuk yang konkret melalui bahasa. Karya sastra juga menjadi cermin kehidupan yang mengandung ajaran-ajaran moral serta berbagai hal yang menyangkut tata pergaulan sesama manusia.

Unsur intrinsik ialah unsur utama yang terdapat pada sebuah karya sastra. Unsur intrinsik merupakan unsur yang membangun sebuah film yang terdapat pada film itu sendiri seperti tema, konflik, alur dan sebagainya yang terkandung pada isi film. Nurgiyantoro (2013) berpendapat bahwa unsur-unsur intrinsik secara langsung ikut serta dalam membangun cerita meliputi: tema, alur, konflik, latar, tokoh, gaya bahasa, sudut pandang dan amanat. Unsur intrinsik merupakan bagian dari lahirnya sebuah karya sastra itu sendiri. Unsur-unsur inilah yang menjadikan terciptanya sebuah karya sastra. Unsur-unsur intrinsik pada film meliputi: tema, alur, tokoh, konflik, gaya bahasa, sudut pandang, latar dan amanat. Sedangkan unsur ekstrinsik pada sebuah karya sastra adalah unsur pendukung yang keberadaannya di luar karya sastra namun sangat memengaruhi keberadaan dari karya sastra tersebut. Unsur ekstrinsik membuat suatu karya sastra memiliki nilai yang terikat dengan sosial masyarakat. Nurgiyantoro (2013) berpendapat bahwa unsur ekstrinsik merupakan unsur-unsur yang keberadaannya di luar karya fiksi sangat berpengaruh terhadap lahirnya sebuah karya, tetapi tidak menjadikan bagian di dalam karya fiksi itu sendiri.

Film merupakan suatu bentuk karya sastra yang menceritakan kisah hidup dalam penyampaiannya dengan lakuan dan dialog. Film adalah miniatur kehidupan yang didasari oleh kenyataan sosial dengan dicampur pemanis oleh sutradara. Oleh karenanya, karya yang dikemas dalam bentuk film adalah bagian dari sastra. Film dirujuk sebuah karya sastra guna dilakukannya penelitian terkait unsur-unsur intrinsik dan unsur ekstrinsik yang terkandung dalam film. film dirujuk sebuah karya sastra guna dilakukannya penelitian terkait unsur-unsur intrinsik dan unsur ekstrinsik yang terkandung dalam film.

Penelitian unsur intrinsik dan ekstrinsik pada film tidak sering dilakukan, namun pernah dilakukan penelitian serupa oleh Darsita Suparno dalam sebuah artikel pada Film Indonesia yang berjudul "Do'a untuk Ayah". Penelitian ini dilakukan pada tinjauan unsur intrinsik dan ekstrinsiknya. Tinjauan pada film dilakukan agar budaya para tokoh serta latar belakang sosial dapat diketahui. Pembahasan film yang dilakukan merupakan bagian karya yang 
ceritanya dari kehidupan sehari-hari serta keadaan politik sedang terjadi pada saat itu yang dicampur dengan ide penulis. Penelitian artikel yang dilakukan untuk mengetahui bentuk tindak tutur yang terdapat pada film "Tilik" mengacu pada tindak tutur ilokusi yaitu deklaratif, imperatif, dan interogatif. Penelitian tindak tutur pada film yang dilakukan menjadi acuan penulis dalam melakukan penelitian sebuah film.

\section{B. METODELOGI PENELITIAN}

Metode penelitian menggunakan metode penelitian kualitatif, sebab dalam tindakannya peneliti mengidentifikasi unsur intrinsik dan unsur ekstrinsik pada film yakni : tema, alur, tokoh, latar, sudut pandang, latar belakang film, nilai moral, kodisi politik negara dan sebagainya. Data yang diperoleh akan dianalisis dan diuraikan secara objektif kemudian dideskripsikan. Anggito, dkk (2018), menyimpulkan bahwa penelitian kualitatif adalah pengumpulan suatu data yang dilakukan secara alamiah dengan tujuan untuk mengartikan fakta atau gejala yang terjadi, di mana peneliti menjadi instrumen utama serta hasil penelitian kualitatif merupakan suatu makna bukan generalisasi. Metode penelitian kualitatif merupakan metode penelitian yang membutuhkan pengertian serta pemahaman mendalam secara menyeluruh. Metode penelitian kualitatif erat hubungannya dengan obyek yang diteliti agar dapat menjawab permasalahan dari data yang didapatkan akan dianalisis oleh penulis yang nantinya akan disimpulkan hasil dari penelitian yang dilakukan dalam kondisi dan situasi tertentu.

Data dalam penelitian bersumber dari film festival anti korupsi tahun 2015 yang berjudul “Tinuk", karya Aprilingga Dani dan diproduksi oleh Mata-Mata Project dengan durasi 15 menit. Data dalam penelitian yaitu unsur intrinsik serta unsur ekstrinsik yang ada pada film tersebut. Adapun teknik unsur penentu (Moleong, 2017) penelitian pada data utama bersumber dari pengamatan tindakan serta kalimat, sedangkan dokumen dan data lain-lain merupakan data tambahan sebagai pelengkap hasil penelitian.

Hasil penelitian bagian pembahasan menggunakan sumber data primer dan data sekunder dalam sajiannya. Data primer adalah pengambilannya data dengan cara instrumen pengamatan, penggunaan dokumen serta catatan. Sumber data primer didapatkan dengan cara pengamatan secara langsung. Adapun dalam melakukan penelitian dengan sumber data primer adalah mengamati objek secara langsung agar mendapatkan data pengamatan yang diperlukan (menonton film Tinuk). Sedangkan data sekunder diperoleh melalui studi 


\section{Lingua Rima: Jurnal Pendidikan Bahasa dan Sastra Indonesia \\ Vol. 11 No. 1 Januari 2022 \\ http://jurnal.umt.ac.id/index.php//grm}

dokumentasi, kepustakaan, majalah, buku, koran dan naskah semua yang berhubungan langsung dengan data penelitian. Sumber sekunder adalah sumber tidak langsung memberikan kontribusi kepada pengumpul data, misalnya lewat buku dan artikel yang mendukung dalam penelitian. Peneliti akan terbantu dengan sumber data sekunder dalam mengumpulkan data-data serta menganalisis hasil dari penelitian yang dapat memperkuat temuan pengamatan serta menghasilkan penelitian yang validitas yang tinggi.

\section{HASIL PENELITIAN DAN PEMBAHASAN}

Penelitian unsur intrinsik dan ektrinsik pada film yang dilakukan, akan dibahas berikut ini. Unsur intrinsik yang menjadi unsur utama atau unsur pokok guna membangun berjalannya cerita dalam sebuah film. Unsur serta penjelasan dari seluruh unsur intrinsik yang terdapat dalam cerita dapat digunakan serta mempermudah dalam menganalisis film. Sedangkan unsur ekstrinsik merupakan unsur-unsur terpenting yang terdapat pada sebuah cerita film. Namun, unsur yang terkandung dalam cerita film tidak hanya unsur-unsur intrinsik saja tetapi ada unsur ekstrinsik yang berpengaruh pada film tersebut.

\section{a. Unsur-Unsur Intrinsik}

Unsur intrinsik yang merupakan unsur inti dalam sebuah cerita untuk membangun cerita film. Unsur intrinsik yang terkandung dalam film memiliki beberapa bagian. Tema merupakan inti cerita. Bermula dari ide awal yang kemudian cerita dibangkitkan oleh penulis dengan menggunakan unsur intrinsik dalam cerita. Tema yang terdapat pada film Tinuk ialah kejujuran. Alur adalah jalan cerita atau peristiwa yang terjadi dalam sebuah cerita memiliki urutan waktu. Alur yang terdapat dalam film Festival Anti Korupsi Tahun 2015 yang berjudul "Tinuk" memiliki alur yang bersifat maju, jalan cerita dimulai dari Maskur seorang sales handphone yang menawarkan ponsel pintar itu kepada seorang ibu rumah tangga yang bernama Tinuk. Tinuk yang tertarik akan ponsel pintar yang ditawarkan oleh Maskur pun membuat Tinuk meminta dibelikan ponsel pintar tersebut kepada suaminya yang bernama Wahono di mana Wahono memiliki profesi sebagai tukang parkir. Namun, karena keterbatasan ekonomi membuat wahono tidak dapat memenuhi keinginan Tinuk tersebut. Tinuk yang sangat ingin memiliki ponsel pinter itu lalu membujuk wahono untuk melakukan hal terpuji dengan cara untuk memakai dan menaikkan uang parkir agar kelebihan uang parkir tersebut dapat digunakan untuk membelikan Tinuk ponsel. Wahono yang mendengar bujukkan Tinuk pun menjadi marah sambil berkata "Gak! seelek elek ku dadi tukang parkir gak katene, aku iki ngentit.”. Tinuk pun merasa kesal dan sedih karena 


\section{Lingua Rima: Jurnal Pendidikan Bahasa dan Sastra Indonesia \\ Vol. 11 No. 1 Januari 2022 \\ http://jurnal.umt.ac.id/index.php/lgrm}

keinginannya tidak terpenuhi. Tidak beberapa lama kemudian Wahono mendengar kabar dari berita bahwa Maskur diamankan polisi karena telah terbukti menjual ponsel palsu (ilegal) Tinuk pun mendengar kabar tersebut dan akhirnya Tinuk tidak meminta ponsel secara paksa lagi kepada Wahono.

Latar cerita film itu sendiri terjadi dengan latar waktu pagi, siang dan malam. Tokoh yang terdapat pada film festival anti korupsi tahun 2015 yang berjudul Tinuk ini tidaklah banyak, film Tinuk yang berdurasi 15.15 menit ini hanya memiliki tiga tokoh, yaitu: Tinuk, Wahono dan Maskur. Sudut pandang Film yang berjudul Tinuk ini memiliki sudut pandang orang pertama, yang diartikan bahwa penulis menempatkan dirinya dalam cerita film tersebut. Hal ini dapat dilihat dari setiap naskah dialog dibawakan oleh para tokoh yang terlibat dalam film Tinuk. Para tokoh atau pemeran pada film anti korupsi tahun 2015 yang berjudul Tinuk menggunakan kata "aku” yang merupakan tokoh "aku” dalam cerita yang berfungsi untuk memberikan penjelasan tentang alur cerita kepada penonton. Amanat yang terkandung dalam film Tinuk disampaikan secara tersirat oleh penulis. Film Tinuk memberikan gambaran nyata bagi penontonnya, bahwasannya korupsi tidak hanya dilakukan oleh pejabat negara saja. Melainkan orang biasa juga mampu melakukan hal tidak terpuji tersebut. Penulis memberikan pesan moral kejujuran untuk para penonton. Kehidupan masyarakat saat ini dengan gaya hidup yang semakin meningkat membuat problem besar bagi sebagian individu untuk dapat melakukan korupsi di pekerjaannya demi memenuhi segala kebutuhan hidup serta gaya hidupnya.

\section{b. Unsur Ekstrinsik}

Unsur ekstrinsik pada film festival anti korupsi tahun 2015 yang berjudul Tinuk tidaklah lepas dari latar belakang film itu sendiri. Latar belakang film termasuk unsur penting terciptanya film tersebut, selain latar belakang sebuah cerita film biasanya dibuat berdasarkan keadaan politik suatu negara serta memberikan pesan moral kepada penonton melalui cerita film yang disajikan. Adapun unsur ekstrinsik yang dapat dibahas dalam film festival anti korupsi tahun 2015 yang berjudul Tinuk ini yaitu 1) Latar belakang film Tinuk ini memiliki latar belakang yang cukup unik, karena terciptanya film Tinuk bermula dari Aprilingga seorang mahasiswa Universitas Muhammadiyah Malang yang berkenalan dengan seorang penjaga parkir di salah satu pertokoan yang ada di Malang. Perkenalan yang tidak sengaja itu membuat Aprilingga terinspirasi untuk mengembangkan idenya menjadikan sebuah film yang mengangkat cerita tetang tukang parkir. Tukang parkir pada 


\section{Lingua Rima: Jurnal Pendidikan Bahasa dan Sastra Indonesia \\ Vol. 11 No. 1 Januari 2022 \\ http://jurnal.umt.ac.id/index.php/lgrm}

umumnya yang diketahui memiliki kesan negatif karena sering tidak memberikan karcis parkir serta menetapkan harga parkir yang tidak sesuai dengan harga yang tertera pada karcis parkir. Aprilingga tergerak hatinya untuk mengubah citra negatif tukang parkir dengan film Tinuk melalui Wahono sebagai peran tukang parkir yang jujur dan sederhana. 2) Kondisi Politik Negara pada film Tinuk Film terkadang dijadikan suatu bahan pementasan dalam memberikan sindiran atau penjelasan kondisi keadaan suatu politik yang sedang dialami pada suatu daerah atau negara. 3) Nilai moral pada Film yang berjudul Tinuk memiliki nilai moral yang patut untuk ditiru dalam menjalani kehidupan sehari-hari. Nilai moral yang terdapat pada film Tinuk meliputi: nilai kejujuran, nilai tanggungjawab, nilai kesederhanaan dan sebagainya yang dapat dijadikan contoh baik bagi para penonton. Isi film memiliki nilai yang berharga untuk ditonton serta ajarkan kepada generasi selanjutnya melihat tontonan yang saat ini semakin memburuk karena sedikitnya nilai moral yang terkandung.

\section{SIMPULAN DAN SARAN}

Hasil analisis pada film Tinuk yang merupakan film yang diikut sertakan lomba dengan program "bikin film bareng komisi pemberantasan korupsi (KPK)". Film festival anti korupsi tahun 2015 yang berjudul Tinuk dapat diambil kesimpulan bahwa dalam film Tinuk yang hanya berdurasi 15 menit ini terkandung makna yang tersirat untuk keadaan dalam kehidupan masyarakat saat ini. Film ber-genre drama ini merupakan bentuk kritik juga sindiran terhadap tindakan korupsi di Indonesia. Film yang terdiri dari tiga tokoh yakni Tinuk, Wahono dan Maskur ini dapat kita jadikan miniatur kehidupan, di mana korupsi dapat dilakukan oleh siapa saja tidak hanya para politik atau pejabat pemerintah seperti yang banyak kita jumpai di televisi. Film Tinuk memberitahu bahwa korupsi dapat terjadi karena tuntutan atau masalah dari rumah. Film Tinuk sebagai objek penelitian ini dapat disimpulkan bahwa terdapat unsur intrinsik serta ekstrinsik yang terdapat dalam sebuah karya sastra. Adapun unsur intrinsik yang terdapat pada film Tinuk, yakni : tema, konflik, tokoh dan penokohan, alut, latar, sudut pandang serta amanat sedangkan unsur ekstrinsik yang terdapat dalam film Tinuk, yaitu : latar belakang film, kondisi politik, nilai moral, nilai religi dan segi ekonomi.

\section{E. DAFTAR PUSTAKA}

Amir, A. 2013. Sastra lisan Indonesia. Yogyakarta: Andi. 
Anggito, Albi dan Setiawan, Johan. 2018. Metodologi Penelitian Kualitatif. Sukabumi Jawa Barat.

Frandika, E., \& Idawati, I. (2020). Tindak Tutur Ilokusi dalam Film Pendek "Tilik (2018)". Pena Literasi, 3(2), 61-69. https://doi.org/10.24853/pl.3.2.61-69 https://jurnal.umj.ac.id/index.php/penaliterasi/article/view/7392

Moleong, J. 2017. Metode Penelitian Kualitatif. Bandung: PT Rosdakarya.

Nurgiantoro, Burhan. 2013. Teori Pengkajian Fiski. Yogyakarta: Gadja Mada University.

Suparno. Film Indonesia “Do'a untuk Ayah” Tinjauan Unsur Intrinsik dan Ekstrinsik. Buletin Al-Turas Fakultas Adab dan Humaniora, Universitas Islam Negeri (UIN) Syarif Hidayatullah Jakarta. 2015. Diambil 22 Febuari 2021 dari Psych INFO database. D Suparno - Buletin Al-Turas, 2015 - journal.uinjkt.ac.id. Message were rely on http://journal.uinjkt.ac.id/index.php/al-turats/article/view/3824

Wahyuni. Analisis Unsur Intrinsik dan Ektrinsik Novel Surat Kecil Untuk Tuhan Karya Agnes Davonar sebagai Sumbangan Materi Bagi Pengajaran Sastra. Diambil 22 febuari 2021. Message were rely on http://repository.umpalembang.ac.id/id/eprint/1199/1/SKRIPSI1005-1710099576 